\title{
Scalable methanol-free production of recombinant glucuronoyl esterase in Pichia pastoris
}

\author{
C. G. Conacher ${ }^{1}$, M. P. García-Aparicio ${ }^{1,2^{*}} \mathbb{D}$, G. Coetzee ${ }^{1}$, W. H. van Zyl² and J. F. Görgens ${ }^{1}$
}

\begin{abstract}
Objective: Glucuronoyl esterase (GE) is an emerging enzyme that improves fractionation of lignin-carbohydrate complexes. However, the commercial availability of GE is limited, which hinders the research of GE-based bioprocesses for its industrial application in lignocellulose biorefineries. This study evaluated a workable, cost-effective, and commercially scalable production strategy to improve the ease of GE-based research. This strategy consisted of a constitutive and methanol-free enzyme production step coupled with a two-step filtration process. The aim was to determine if this strategy can yield copious amounts of GE, by secretion into the extracellular medium with an acceptable purity that could allow its direct application. This approach was further validated for cellobiose dehydrogenase, another emerging lignocellulose degrading enzyme which is scarcely available at high cost.

Results: The secreted recombinant enzymes were functionally produced in excess of levels previously reported for constitutive production (1489-2780 $\mathrm{mg} \mathrm{L}^{-1}$ ), and were secreted at moderate to high percentages of the total extracellular protein (51-94\%). The constant glycerol feed, implemented during fed-batch fermentation, lead to a decline in growth rate and plateaued productivity. Tangential flow ultrafiltration was used to concentrate cell-free enzyme extracts 5-6-fold, reaching enzyme activity levels (1020-202 $\left.\cup L^{-1}\right)$ that could allow their direct application.
\end{abstract}

Keywords: Glucuronoyl esterase, Cellobiose dehydrogenase, Methanol-free constitutive expression system, Pichia pastoris, Lignocellulose biorefinery enzymes, Enzyme bioprocess technology

\section{Introduction}

Glucuronoyl esterase (GE) is a recently defined carbohydrate esterase that has been isolated from several microorganisms [1-6]. GE has potential for production of biofuels and biomaterials in lignocellulose biorefineries [7-12]. GE cleaves alkali-labile bonds from the lignincarbohydrate complexes at acidic $\mathrm{pH}$ [12]. Recent reports have proven that the removal of glucuronic acid branches from the hemicellulose significantly improved release of fermentable sugars for biofuels production [7, 8, 13]. Additionally, GE can produce bioactive molecules that can be used in the cosmetic and pharmaceutical sectors [12].

\footnotetext{
*Correspondence: garcia@sun.ac.za; mdpgaparicio2012@gmail.com ${ }^{1}$ Departments of Process Engineering, Stellenbosch University, Private Bag X1, Matieland 7602, South Africa

Full list of author information is available at the end of the article
}

Despite the industrial potential of GE, very limited recombinant production has been reported. Pure commercial preparations of GE do not exist. This is an impedance in the development of GE-based bioprocesses, since each study must first produce and purify the enzyme before it is possible to determine its lignocellulosic degrading capabilities. Some commercial enzyme cocktails exist with low GE side activity ([14], this study), but these cocktails do not allow for the determination of specific catalytic roles of each enzyme. To harness the catalytic ability of GE, understand its specific role, and determine optimum dosages, pure enzyme preparations are required. Notably, the recent increase in publications which evaluate application of GE, show an urgent need for GE production [7-10, 12].

Considering the above restriction in GE availability, this study sought to create a 'plug-and-play' system for production of large amounts of GE. The production 
process was designed with commercial and industrial foresight, seeking to keep the process as straightforward, safe, and cost effective as possible, while limiting any proprietary restrictions. The use of a constitutive, patentfree, $\mathrm{P}_{\mathrm{GAP}}$-Pichia pastoris (glyceraldehyde-3-phosphate dehydrogenase promoter) expression system, to produce Hypocrea jecorina GE at bioreactor scale was investigated. Both the enzyme production itself as well as downstream processing of the enzyme into a stable product were considered (Additional file 1: Fig. S1). The feasibility of this approach was further tested for another emerging enzyme of limited commercial availability, Neurospora crassa cellobiose dehydrogenase (CDH). $\mathrm{CDH}$ finds application in multiple areas including bioremediation, textile, biomedicine, biosensors and biofuels [15]. $\mathrm{CDH}$ could improve the saccharification of pre-treated lignocellulose through reduction of end-product inhibition and catalytic activation of lytic polysaccharide monooxygenase [16]. This type of studies is necessary to facilitate research of the functionality and application of GE and other emerging enzymes such as $\mathrm{CDH}$.

\section{Main text \\ Methods \\ Construction of the production strains}

The P. pastoris type strain DSMZ 70382 (CBS704) (DSMZ German Collection of Microorganisms and Cell Cultures) was selected as the expression host. The commercial pJexpress 905 (pJ905) vector (ATUM, USA) containing the $\mathrm{P}_{\mathrm{GAP}}$ and alcohol oxidase I (AOX1) terminator, was used to generate constructs for GE (AAP57749.1) and CDH (XM_951498.2) expression and secretion. Details of cloning, transformation, confirmation and screening procedures are described in [17]. The transformant showing the best production during screening in shake flasks for each enzyme was selected for production at bioreactor scale.

\section{Bioreactor cultivations}

The inoculum preparation and fermentation procedure were conducted as described in Invitrogen guidelines [18, 19]. Fermentations were conducted in $14 \mathrm{~L}$ New Brunswick Bioflo 110 bioreactors, using BioCommand ${ }^{\circledR}$ software (Version 3.30 Plus, New Brunswick Scientific Co. Inc.). The fermentation conditions were identical for all fermentations: $30^{\circ} \mathrm{C}$, pH 5 (combination glass pH probe Mettler Toledo), dissolved oxygen (DO) maintained at $30 \%$ (polarographic DOT probe, Mettler Toledo), and an aeration rate of $1 \mathrm{vvm}$. The fed-batch stage was initiated after depletion of glycerol, where $4 \mathrm{~L}$ of $50 \%\left(\mathrm{w} \mathrm{v}^{-1}\right)$ glycerol feed, supplemented with $\mathrm{PTM}_{1}$ trace salts solution $\left(1.2 \% \mathrm{v} \mathrm{v}^{-1}\right)$, was fed at a constant rate of $72.6 \mathrm{~mL} \mathrm{~h}^{-1}$.
The fed-batch stage was concluded after approximately $48 \mathrm{~h}$, when the feed was depleted.

Samples taken $(10 \mathrm{~mL})$ during fermentation were analysed for biomass (dry cell weight, $\mathrm{g}_{\mathrm{DCW}} \mathrm{L}^{-1}$ ) enzyme activity $\left(\mathrm{U} \mathrm{L}^{-1}\right)$ as described in $[17,20,21]$, and glycerol concentration [22] (during fed-batch stage). The final samples were used to determine total protein concentrations [bicinchoninic acid $\left(\mathrm{BCA}^{\mathrm{TM}}\right)$ microassay (Sigma-Aldrich, USA)] and target protein concentrations [densitometry of tris-tricine sodium dodecyl sulphate polyacrylamide gel electrophoresis (SDS-PAGE) [23] image using Image ${ }^{\circledR}$ software]. Maximum growth rate $\left(\mu_{\max }\right)$ was graphically calculated during the exponential growth phase of the batch phase. All trends were fitted to a linear regression with $R^{2}$ values of above 0.98 .

\section{Concentration of crude enzyme extracts}

The culture was harvested immediately after the fedbatch phase to minimize protease degradation of the enzyme product. The total culture was centrifuged (8000 rpm; $4{ }^{\circ} \mathrm{C} ; 10 \mathrm{~min}$ ) and subjected to a two-step filtration process. The Pellicon 2.0 tangential flow filtration apparatus (Merck, South Africa) was used as per the manual instructions. The feed and retentate pressure were maintained at a maximum of 10 and 2 bar, respectively. The transmembrane pressure (TMP) was 2.5 bar. The supernatant was first filtered through a $0.22 \mu \mathrm{m}$ filter cassette (Durapore ${ }^{\circledR}$ PVDF, Merck Millipore), then concentrated by ultrafiltration using a $5 \mathrm{kDa}$ filter cassette (Biomax $^{\mathrm{TM}} 5$, Merck Millipore). Once the volume of the retentate/feeding reservoir was decreased tenfold, the process was complete. Samples of each permeate and retentate were analysed for volumetric activity. Volumes of the feed, permeate and retentate of each filtration process were measured.

\section{Results and discussion \\ Glycerol fed-batch fermentation kinetics, yields and productivity for GE and $C D H$}

The growth and enzyme production characteristics of the created recombinant strains were evaluated using bioreactor cultivations. GE side-activity of three commercial enzyme cocktails, namely Celluclast ${ }^{\circledR} 1.5$ L (Novozymes, 27.47 $\mathrm{U} \mathrm{L}^{-1}$ ), Depol ${ }^{\mathrm{TM}} 740 \mathrm{~L}$ A (Biocatalysts, $10.70 \mathrm{U} \mathrm{L}^{-1}$ ) and Depol ${ }^{\mathrm{TM}} 740 \mathrm{~L} \mathrm{~B}$ (Biocatalysts, $7.72 \mathrm{U} \mathrm{L}^{-1}$ ) were tested to serve as a comparative baseline. The bioreactor cultivation for expression of GE returned a final volumetric activity yield of $238.17 \mathrm{U} \mathrm{L}^{-1}$, and a final recombinant protein titre of $2778.01 \mathrm{mg} \mathrm{L}^{-1}$ (Fig. 1a; Table 1), well in excess of previous attempts involving methanol induction of GE [5, 24]. Notably, the volumetric activity was well above the side activities of the commercial enzyme cocktails tested here $\left(7.72-27.47 \mathrm{U} \mathrm{L}^{-1}\right)$. Bioreactor 

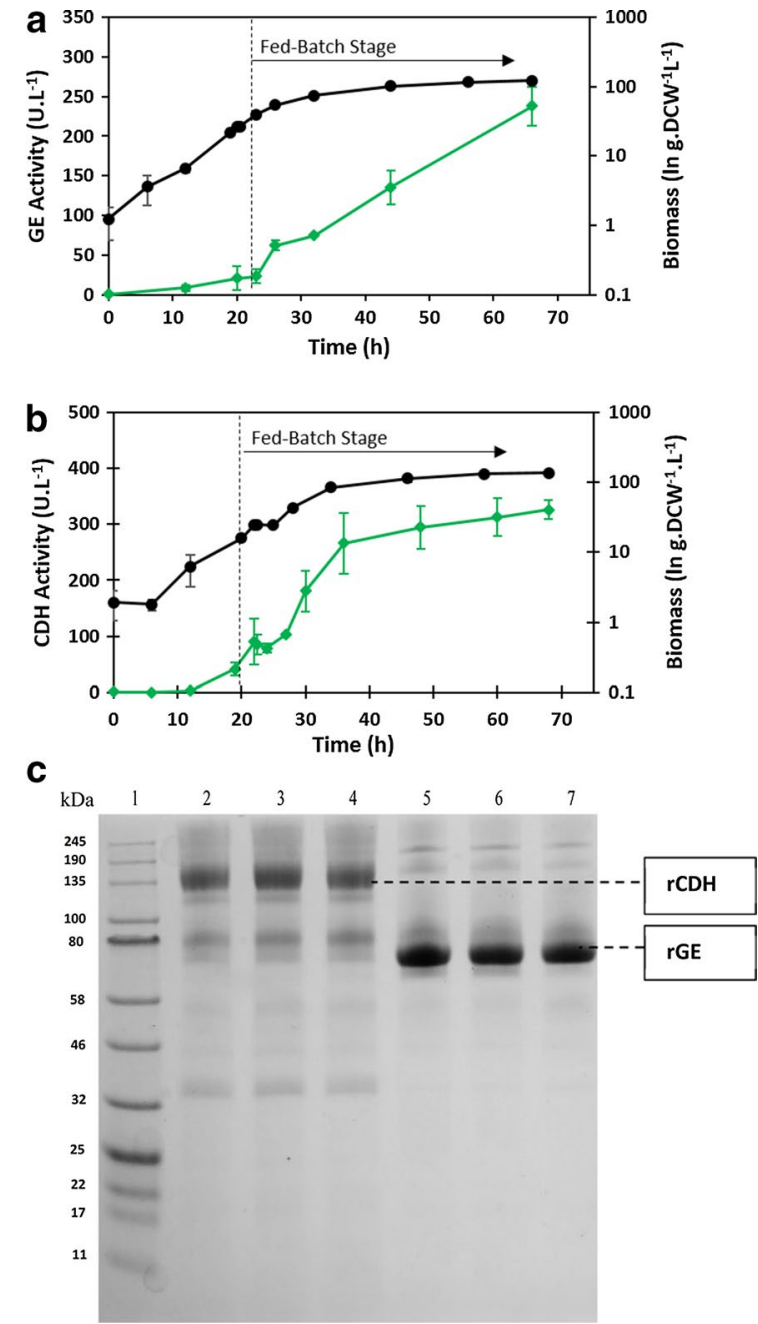

Fig. 1 Volumetric activity (green diamond) and biomass yields (dry cell weight per litre) (black circle) during bioreactor cultivations of each target protein. Arrows indicate the initiation of the glycerol fed-batch phase (20-22 h), where a 50\% (w.v $\left.\mathrm{v}^{-1}\right)$ glycerol feed supplemented with trace salts was added at a rate of $72.6 \mathrm{~mL} / \mathrm{h}$. a Glucuronoyl esterase (GE) b Cellobiose Dehydrogenase (CDH). Error bars indicate standard deviation from mean of three fermentation replicates. c SDS-PAGE analysis of final fermentation samples (each lane representing one replicate of a bioreactor fermentation) of $20 \mu \mathrm{L}$ supernatant containing the target proteins. Lane 1: Protein molecular weight marker. Lane 2-4: $\mathrm{CDH}$-containing supernatant $(\mathrm{rCDH}, 127$ $\mathrm{KDa}$ ). Lanes 5-7: Glucuronoyl esterase-containing supernatant (rGE, $78 \mathrm{KDa})$

cultivation for $\mathrm{CDH}$ production returned a final mean volumetric activity of $329.49 \mathrm{U} \mathrm{L}^{-1}$ and a final mean recombinant protein concentration of $1489.30 \mathrm{mg} \mathrm{L}^{-1}$ (Fig. 1b; Table 1). Although the protein concentration of secreted CDH reported here $\left(1489.30 \mathrm{mg} \mathrm{L}^{-1}\right)$ is an improvement on previous attempts at methanol-induced expression, the volumetric activity and specific activity is lower than previously reported [21, 25-27]. Lowered specific activity has been observed in recombinant $\mathrm{CDH}$ production by $P$. pastoris due to a sub-stoichiometric occupation of catalytic sites within the flavin adenine dinucleotide (FAD) cofactor, as well as hyper-glycosylation [28]. Further, hyper-glycosylation may have affected the specific activity of both target enzymes, since the reported protein sizes (Fig. 1c; CDH: $127 \mathrm{kDa}$; GE: $78 \mathrm{kDa}$ ) are larger than the expected, in silico protein sizes (ExPASy: CDH: $88.46 \mathrm{kDa}$; GE: $81.29 \mathrm{kDa}$ [2, 29].

The general trends observed for the fermentations are as follows (Fig. 1a, b). During the batch phase, an initial lag phase of less than $6 \mathrm{~h}$ was observed, corresponding to minimal volumetric activity, followed by an exponential growth phase, where linear increases in volumetric activity were observed until the end of the batch phase (between 20 and $22 \mathrm{~h}$ ). During the glycerol fedbatch stage, there was a brief exponential growth phase of approximately $6 \mathrm{~h}$, followed by an extended growth phase. During this continuous growth phase, the agitation of the bioreactor remained at the maximum (1000 rpm), and oxygen sparging was required throughout to maintain sufficient availability of DO (30\%) in the culture.

The $\mu_{\max }$ was determined during the batch phase under identical growth conditions (Table 1). GE- and CDHexpressing $P$. pastoris strains had similar $\mu_{\max }$ values of $0.15 \mathrm{~h}^{-1}$ and $0.16 \mathrm{~h}^{-1}$ respectively, within expected values reported for recombinant $P$. pastoris strains using glycerol $\left(0.15-0.20 \mathrm{~h}^{-1}\right)[30,31]$. Similarly, the biomass yields obtained (120.94, $136.47 \mathrm{~g}_{\mathrm{DCW}} \mathrm{L}^{-1}$; Table 1) were comparable to previous bioreactor cultivations of recombinant P. pastoris $[18,32]$.

A decrease in specific growth rate, modelled as a power regression (GE: $20979 \mathrm{x}^{-3.63} ; \mathrm{R}^{2}=0.9871 ; \mathrm{CDH}$ : $\left.885.76 \mathrm{x}^{-2.852} ; \mathrm{R}^{2}=0.9882\right)$, was observed during the fedbatch process (Additional file 2: Fig. S2), during which the levels of glycerol remained below detectable HPLC levels. This is attributed to the fact that the amount of biomass in the fermentation vessel increased with time (Additional file 2: Fig. S2), while the amount of glycerol fed into the bioreactor remained constant, effectively decreasing the ratio of available carbon source per gram of biomass. This growth rate decline has been suggested to be the concluding stage of an ideal growth rate time course for a number of secreted protein fermentations in P. pastoris [30, 33, 34].

Specific productivity describes the efficiency of the process by quantifying the amount of recombinant enzyme secreted per gram of biomass per hour. Maximum values of specific productivity $\left(\mathrm{q}_{\mathrm{p} \text { max }}\right)$ of protein secretion were reached during the batch phase (1.22, $0.76 \mathrm{mg}$ recombinant protein.biomass ${ }^{-1} \mathrm{~h}^{-1}$ for 
Table 1 Summary of enzymatic yields, kinetics and productivity for bioreactor cultivations of recombinant $P$. pastoris at the end of the glycerol fed-batch stage, and comparisons to previous expression attempts

\begin{tabular}{|c|c|c|c|c|c|c|}
\hline Parameter & $\begin{array}{l}\text { GE } \\
\text { (this study) }\end{array}$ & $\begin{array}{l}\text { GE } \\
\text { (previous } \\
\text { studies) }\end{array}$ & Reference & $\begin{array}{l}\mathrm{CDH} \\
\text { (this study) }\end{array}$ & $\begin{array}{l}\mathrm{CDH} \\
\text { (previous } \\
\text { studies) }\end{array}$ & Reference \\
\hline Highest Volumetric Activity $\left(\mathrm{U} \mathrm{L}^{-1}\right)$ & 238.17 & $5.7^{\mathrm{a}}$ & Topakas et al. [5] & 329.49 & $7955^{\mathrm{a}}$ & Stapleton et al. [26] \\
\hline Highest Recombinant Protein Titre $\left(\mathrm{mg} \mathrm{L}^{-1}\right)$ & 2778.01 & NR & - & 1489.30 & $633^{b}$ & Ma et al. [28] \\
\hline$\%$ recombinant protein vs total protein in supernatant & $93.61 \%$ & & - & $50.89 \%$ & NR & - \\
\hline Biomass concentration $\left(g_{D C W} L^{-1}\right)$ & 120.94 & & - & 136.47 & & - \\
\hline$\mu_{\max }\left(h^{-1}\right)$ & 0.15 & & - & 0.16 & & - \\
\hline $\left.\mathrm{q}_{\text {p.max }}(\mathrm{mg} \text { recombinant protein.[g biomass } \cdot \mathrm{h}]^{-1}\right)$ & 1.22 & & - & 0.76 & & - \\
\hline$q_{p . m e a n}\left(m g\right.$ recombinant protein. $\left.[\mathrm{g} \text { biomass } \cdot h]^{-1}\right)$ & 0.52 & & - & 0.43 & & - \\
\hline
\end{tabular}

NR Not reported

${ }^{a}$ At shake flask scale, under methanol-induced $P_{A O X 1}$ regulation

${ }^{b}$ At $7 \mathrm{~L}$ bioreactor scale, under methanol-induced $\mathrm{P}_{\mathrm{AOX} 1}$ regulation

Table 2 Summary of volumetric activity and protein concentration values at successive steps of tangential flow filtration concentration of cell-free extracts obtained from bioreactor fermentations

\begin{tabular}{|c|c|c|c|c|c|}
\hline & Step & $\begin{array}{l}\text { Volumetric activity } \\
\left(U L^{-1}\right)\end{array}$ & Total activity (U) & $\begin{array}{l}\text { Yield (\%, volumetric } \\
\text { activity) }\end{array}$ & $\begin{array}{l}\text { Total protein } \\
\text { concentration } \\
\left(\mathrm{g} \mathrm{L}^{-1}\right)\end{array}$ \\
\hline \multirow[t]{4}{*}{ GE } & CFE & 203.92 & 407.84 & 100.00 & 2.93 \\
\hline & MFP & 196.07 & 352.93 & 86.54 & - \\
\hline & UFR & 1019.61 & 203.92 & 50.00 & 8.31 \\
\hline & UFP & 2.11 & 2.95 & - & - \\
\hline \multirow[t]{4}{*}{$\mathrm{CDH}$} & CFE & 40.77 & 81.54 & 100.00 & 2.97 \\
\hline & MFP & 39.34 & 70.81 & 86.84 & - \\
\hline & UFR & 202.08 & 40.42 & 49.57 & 10.16 \\
\hline & UFP & 0.03 & 0.04 & - & - \\
\hline
\end{tabular}

CFE cell-free extract, MFP microfiltration permeate, UFR ultrafiltration retentate or concentrated enzyme, UFP ultrafiltration permeate

GE and CDH, respectively; Table 1). During the fedbatch stage, specific productivity remained constant at a lowered value close to the mean specific productivity value $\left(\mathrm{q}_{\mathrm{p} . \text { mean }}\right)(0.52$ and $0.43 \mathrm{mg}$ recombinant protein.biomass ${ }^{-1} \mathrm{~h}^{-1}$ for $\mathrm{GE}$ and $\mathrm{CDH}$, respectively), resulting in $\mathrm{GE}$ and $\mathrm{CDH}$ accumulation throughout the fed-batch stage (Fig. 1a, b). This has been observed in previous constant fed-batch cultivations of recombinant $\mathrm{P}_{\mathrm{GAP}}-P$. pastoris $[33,35]$. The productivity could be increased by manipulating the growth rate such that an extended growth phase at $\mu_{\max }$ is maintained before the end-phase decline in growth rate [31, 33-35]. This is achieved by an increasing (linear or exponential) glycerol feeding rate during the fed-batch stage. The optimal duration of the phase at which $\mu_{\max }$ is maintained differs between recombinant strains and should be optimised on a case-by-case basis.
Concentration of crude enzyme extracts by tangential flow ultrafiltration (TFU)

The final secreted protein concentrations differed between enzymes, probably due to protein-specific factors associated with the secretion process. The heterologous proteins were secreted at moderate (CDH: 50.89\%) to high (GE: $93.61 \%$ ) percentages of the total extracellular protein, as determined by densitometry analyses (Fig. 1c). $\mathrm{CDH}$ and GE were, therefore, the major proteins present in the fermentation broth. While native, extracellular $P$. pastoris proteins were present in the fermentation broth (Fig. 1c), these were devoid of any contaminating enzymatic activity (as determined with the use of a negative control strain), which allows for simple and economical downstream processing, contributing to the affordability and accessibility of the process.

The harvested supernatant was concentrated using TFU (Table 2). The microfiltration process returned satisfactory volumetric activity yields (GE: $86.84 \%, \mathrm{CDH}$ : 
86.54\%; Table 2), and the loss in activity units can be explained by the inherent loss of sample volume in the filtration apparatus itself. The total protein concentration in the enzyme extracts was increased 3.69-, 2.84-fold for $\mathrm{GE}$ and $\mathrm{CDH}$, respectively. In terms of volumetric activity, GE and CDH were concentrated 4.95-, and 5.20-fold, respectively. The ultrafiltration process returned volumetric activity yields that were acceptable (49.57 and $50.00 \%)$, but lower than expected [26, 36-38] despite acceptable integrity of membrane (permeate with minimal volumetric activity $0.00-2.95 \mathrm{U}_{\text {Total }} \mathrm{L}^{-1}$ ). It is therefore hypothesised that the recombinant protein is being retained or degraded in the filtration apparatus itself, as proteins can adsorb to membranes, often causing permanent fouling [39] and the formation of a protein monolayer on the surface of the membrane [40]. Despite these shortcomings, the final concentrated enzyme products could be used directly on lignocellulose according to enzyme dosages established in previous studies $[2,41]$.

\section{Limitations}

This is the first report of GE secretion yields under constitutive expression, and the second report of bioreactor heterologous production [9]. This work demonstrates the feasibility of a constitutive, methanol-free $P$. pastoris expression system for production of emerging lignocellulose-degrading enzymes such as GE. The bioprocess reported here returned high protein yields of active GE and shows promise for different enzymes as well, including $\mathrm{CDH}$ (Additional file 1: Fig. S1). However, the constant specific productivity and the lack of an extended $\mu_{\max }$ phase during the fed-batch cultivation shows potential for improvement of secretion levels through manipulating the growth rate. TFU concentrated the enzyme extracts to suitable dosages for lignocellulose application studies but showed inefficient volumetric activity yields. This is significant due to the economic implications at manufacturing scale, therefore optimization of the ultrafiltration process is recommended. Future studies should also confirm the application of the concentrated recombinant enzymes on industrially relevant substrates.

\section{Supplementary information}

Supplementary information accompanies this paper at https://doi. org/10.1186/s13104-019-4638-9.

Additional file 1: Figure S1. Illustration showing the strategy applied for the production of glucuronoyl esterase (GE) and cellobiose dehydrogenase $(\mathrm{CDH})$ enzymes and the summary of main results.

Additional file 2: Figure S2. Exponential decline in specific growth rate during glycerol fed-batch stage of the bioreactor cultivation, with a constant glycerol feed of $72.6 \mathrm{~mL} / \mathrm{h}$. of (A): Glucuronoyl esterase; (B): Cellobiose dehydrogenase.

\section{Abbreviations}

AOX1: alcohol oxidase 1; CDH: cellobiose dehydrogenase; CFE: cell-free extract; DO: dissolved oxygen; DCW: dry cell weight; GE: glucuronoyl esterase; MFP: microfiltration permeate; $P_{G A P}$ : glyceraldehyde-3-phosphate dehydrogenase promoter; qp.max: maximum specific productivity, mg recombinant protein. biomass ${ }^{-1} \mathrm{~h}^{-1}$; qp.mean: mean specific productivity, mg recombinant protein. biomass ${ }^{-1} \mathrm{~h}^{-1}$; SDS-PAGE: sodium dodecyl sulphate polyacrylamide gel electrophoresis; TFU: tangential flow ultrafiltration; TMP: transmembrane pressure; UFP: ultrafiltration permeate; UFR: ultrafiltration retentate or concentrated enzyme; $\mathrm{UL}^{-1}$ : units of enzymatic activity per litre; vvm: volume per volume per minute; $\mu$ : specific growth rate; $\mu_{\max }$ : maximum specific growth rate.

\section{Acknowledgements}

Novozymes and Biocatalysts are thanked for supplying the commercial enzyme preparations. Mr Arrie Arends, Dr Kim Trollope and Dr Rose Cripwell from Stellenbosch University are thanked for technical assistance with the bioreactors, molecular work and HPLC samples, respectively. Renewable and Sustainable Energy Scholarships (RSES) are thanked for their financial support.

\section{Authors' contributions}

$J G, E V Z$ and MGA conceived the project. JG and MGA supervised the study. CC and MGA constructed the recombinant strains. CC performed the screening in shake flasks and fermentations at bioreactor scale. CC wrote first draft of manuscript with assistance of MGA. GC assisted with bioreactor experiments. All authors discussed the results and provided critical feedback. All authors read and approved the final manuscript.

\section{Funding}

This work was funded by the South African National Research Foundation (NRF) and the South African Biofuels Research Chair. These funding bodies had no role in: the design of this study, collection, analysis, and interpretation of data and in writing the manuscript.

\section{Availability of data and materials}

Tabulated data of graphs reported in this study are available in Ref. [17] (Addendum D): https://pdfs.semanticscholar.org/4a02/774e4d4f01751b0 140a315b617bb36d233ff.pdf.

\section{Ethics approval and consent to participate}

Not applicable.

\section{Consent for publication \\ Not applicable.}

\section{Competing interests}

The authors declare that they have no competing interests.

\section{Author details}

${ }^{1}$ Departments of Process Engineering, Stellenbosch University, Private Bag X1, Matieland 7602, South Africa. ${ }^{2}$ Departments of Microbiology, Stellenbosch University, Private Bag X1, Matieland 7602, South Africa.

Received: 7 Auqust 2019 Accepted: 11 September 2019 Published online: 18 September 2019

References

1. Špániková S, Biely P. Glucuronoyl esterase-novel carbohydrate esterase produced by Schizophyllum commune. FEBS Lett. 2006;580(19):4597-601.

2. d'Errico C, Jørgensen JO, Krogh KBRM, Spodsberg N, Madsen R, Monrad RN. Enzymatic degradation of lignin-carbohydrate complexes (LCCs): model studies using a fungal glucuronoyl esterase from Cerrena unicolor. Biotechnol Bioeng. 2015;112:914-22. https://doi.org/10.1002/bit.25508.

3. Ďuranová M, Špániková S, Wösten HA, Biely P, De Vries RP. Two glucuronoyl esterases of Phanerochaete chrysosporium (a). Arch Microbiol. 2009;191:133-40. https://doi.org/10.1007/s00203-008-0434-y.

4. Li XL, Špániková S, de Vries RP, Biely P. Identification of genes encoding microbial glucuronoyl esterases. FEBS Lett. 2007;581:4029-35. https://doi. org/10.1016/j.febslet.2007.07.041. 
5. Topakas E, Moukouli M, Dimarogona M, Vafiadi C, Christakopoulos P. Functional expression of a thermophilic glucuronyl esterase from Sporotrichum thermophile: identification of the nucleophilic serine. Appl Microbiol Biotechnol. 2010;87:1765-72. https://doi.org/10.1007/s00253-010-2655-7.

6. Vafiadi C, Topakas E, Biely P, Christakopoulos P. Purification, characterization and mass spectrometric sequencing of a thermophilic glucuronoyl esterase from Sporotrichum thermophile. FEMS Microbiol Lett. 2009;296:178-84. https ://doi.org/10.1111/j.1574-6968.2009.01631.x.

7. Arnling Bååth J, Giummarella N, Klaubauf S, Lawoko M, Olsson L. A glucuronoyl esterase from Acremonium alcalophilum cleaves native lignin-carbohydrate ester bonds. FEBS Lett. 2016;590:2611-8. https://doi. org/10.1002/1873-3468.12290.

8. d'Errico C, Börjesson J, Ding H, Krogh KBRM, Spodsberg N, Madsen R, Monrad $\mathrm{RN}$. Improved biomass degradation using fungal glucuronoyl-esteraseshydrolysis of natural corn fiber substrate. J Biotechnol. 2016;219:117-23. https://doi.org/10.1016/j.jbiotec.2015.12.024.

9. Mosbech C, Holck J, Meyer AS, Agger JW. The natural catalytic function of CUGE glucuronoyl esterase in hydrolysis of genuine lignin-carbohydrate complexes from birch. Biotechnol Biofuels. 2018;11:1-9. https://doi. org/10.1186/s13068-018-1075-2.

10. Tang J, Long L, Cao Y, Ding S. Expression and characterization of two glucuronoyl esterases from Thielavia terrestris and their application in enzymatic hydrolysis of corn bran. Appl Microbiol Biotechnol. 2019;103(7):3037-48. https://doi.org/10.1007/s00253-019-09662-w.

11. Balakshin M, Capanema E, Gracz H, Chang H, Jameel H. Quantification of lignin-carbohydrate linkages with high-resolution NMR spectroscopy. Planta. 2011:6:1097-110.

12. Hüttner S, Klaubauf S, de Vries RP, Olsson L. Characterisation of three fungal glucuronoyl esterases on glucuronic acid ester model compounds. Appl Microbiol Biotechnol. 2017;101(13):5301-11. https://doi.org/10.1007/s0025 3-017-8266-9.

13. Lyczakowski JJ, Wicher KB, Terrett OM, Faria-Blanc N, Yu X, Brown D, Krogh KBRM, Dupree P, Busse-Wicher M. Removal of glucuronic acid from xylan is a strategy to improve the conversion of plant biomass to sugars for bioenergy. Biotechnol Biofuels. 2017;10:224. https://doi.org/10.1186/s1306 8-017-0902-1.

14. Fraňová L, Puchart V, Biely P. $\beta$-Glucuronidase-coupled assays of glucuronoyl esterases. Anal Biochem. 2016;510:114-9.

15. Nyanhongo GS, Thallinger B, Guebitz GM. Cellobiose dehydrogenase-based biomedical applications. Process Biochem. 2017;59:37-45. https://doi. org/10.1016/j.procbio.2017.02.023.

16. Kracher D, Ludwig R. Cellobiose dehydrogenase: an essential enzyme for lignocellulose degradation in nature-a review. Bodenkultur. 2016;67:145-63. https://doi.org/10.1515/boku-2016-0013.

17. Conacher C. Constitutive expression of enzymes in Pichia pastoris for use in lignin valorisation. MSc thesis, Stellenbosch University; 2018. https://pdfs. semanticscholar.org/4a02/774e4d4f01751b0140a315b617bb36d233ff.pdf.

18. Anane E, van Rensburg E, Görgens JF. Comparison of constitutive and inducible $\beta$-fructofuranosidase production by recombinant Pichia pastoris in fed-batch culture using defined and semi-defined media. SAJCE. 2016;22:17-22. https://doi.org/10.1016/j.sajce.2016.10.001.

19. Invitrogen 2013. Pichia fermentation process guidelines version B 05300231 .

20. Sunner H, Charavgi MD, Olsson L, Topakas E, Christakopoulos P. Glucuronoyl esterase screening and characterization assays utilizing commercially available benzyl glucuronic acid ester. Molecules. 2015;20:17807-17. https://doi. org/10.3390/molecules201017807.

21. Sygmund C, Santner P, Krondorfer I, Peterbauer CK, Alcalde M, Nyanhongo GS, Guebitz GM, Ludwig R. Semi-rational engineering of cellobiose dehydrogenase for improved hydrogen peroxide production. Microb Cell Fact. 2013;12:38. https://doi.org/10.1186/1475-2859-12-38.

22. Cripwell RA, Rose $\mathrm{SH}$, van Zyl WH. Expression and comparison of codon optimised Aspergillus tubingensis amylase variants in Saccharomyces cerevisiae. FEMS Yeast Res. 2017;17:1-12. https://doi.org/10.1093/femsyr/fox040.

23. Gallagher SR. One-dimensional SDS gel electrophoresis of proteins. Current protocols in protein. Science. 2012. https://doi.org/10.1002/04711 40864.ps1001s68.

24. Dilokpimol A, Mäkelä MR, Cerullo G, Zhou M, Varriale S, Gidijala L, Brás JLA, Jütten P, Piechot A, Verhaert R, Faraco V, Hilden KS, de Vries RP. Fungal glucuronoyl esterases: genome mining based enzyme discovery and biochemical characterization. New Biotechnol. 2018;40:282-7. https://doi. org/10.1016/j.nbt.2017.10.003.

25. Bey M, Berrin J-G, Poidevin L, Sigoillot J-C. Heterologous expression of Pycnoporus cinnabarinus cellobiose dehydrogenase in Pichia pastoris and involvement in saccharification processes. Microb Cell Fact. 2011;10:113. https://doi.org/10.1186/1475-2859-10-113.

26. Stapleton PC, O'Brien MM, O'Callaghan J, Dobson ADW. Molecular cloning of the cellobiose dehydrogenase gene from Trametes versicolor and expression in Pichia pastoris. Enzyme Microb Technol. 2004;34:55-63. https://doi. org/10.1016/j.enzmictec.2003.08.006.

27. Zhang R, Fan Z, Kasuga T. Expression of cellobiose dehydrogenase from Neurospora crassa in Pichia pastoris and its purification and characterization. Protein Expr Purif. 2011;75:63-9. https://doi.org/10.1016/j.pep.2010.08.003.

28. Ma S, Preims M, Piumi F, Kappel L, Seiboth B, Record E, Kracher D, Ludwig R. Molecular and catalytic properties of fungal extracellular cellobiose dehydrogenase produced in prokaryotic and eukaryotic expression systems. Microb Cell Fact. 2017;16:37. https://doi.org/10.1186/s12934-017-0653-5.

29. Zhang R, Xu C, Shen Q, Kasuga T, Wu W, Szewczyk E, Ma D, Fan Z. Characterization of two cellobiose dehydrogenases and comparison of their contributions to total activity in Neurospora crassa. Int Biodeterior Biodegrad. 2013;82:24-32. https://doi.org/10.1016/j.ibiod.2013.03.017.

30. Buchetics M, Dragosits M, Maurer M, Rebnegger C, Porro D, Sauer M, Gasser B, Mattanovich D. Reverse engineering of protein secretion by uncoupling of cell cycle phases from growth. Biotechnol Bioeng. 2011;108:2403-12. https://doi.org/10.1002/bit.23198.

31. Looser V, Brühlmann B, Bumbak F, Stenger C, Costa M, Camattari A, Fotiadis D, Kovar K. Cultivation strategies to enhance productivity of Pichia pastoris: a review. Biotechnol Adv. 2014;33:1177-93. https://doi.org/10.1016/j.biote chadv.2015.05.008.

32. Hong F, Meinander NQ, Jönsson $\sqcup$. Fermentation strategies for improved heterologous expression of laccase in Pichia pastoris. Biotechnol Bioeng. 2002;79:438-49.

33. Maurer M, Kühleitner M, Gasser B, Mattanovich D. Versatile modeling and optimization of fed batch processes for the production of secreted heterologous proteins with Pichia pastoris. Microb Cell Fact. 2006;5:37. https://doi. org/10.1186/1475-2859-5-37.

34. Zhang W, Sinha J, Smith LA, Inan M, Meagher MM. Maximization of production of secreted recombinant proteins in Pichia pastoris fed-batch fermentation. Biotechnol Prog. 2005;21:386-93. https://doi.org/10.1021/bp049811n.

35. Heiss S, Maurer M, Hahn R, Mattanovich D, Gasser B. Identification and deletion of the major secreted protein of Pichia pastoris. Appl Microbiol Biotechnol. 2013;97:1241-9. https://doi.org/10.1007/s00253-012-4260-4.

36. Colao MC, Lupino S, Garzillo AM, Buonocore V, Ruzzi M. Heterologous expression of Icc1 gene from Trametes trogii in Pichia pastoris and characterization of the recombinant enzyme. Microb Cell Fact. 2006;5:31. https://doi. org/10.1186/1475-2859-5-31

37. Li Q, Pei J, Zhao L, Xie J, Cao F, Wang G. Overexpression and characterization of laccase from Trametes versicolor in Pichia pastoris. Appl Biochem Microbiol. 2014;50:140-7. https://doi.org/10.1134/S0003683814020124.

38. Zhong X, Peng L, Zheng S, Sun Z, Ren Y, Dong M, Xu A. Secretion, purification, and characterization of a recombinant Aspergillus oryzae tannase in Pichia pastoris. Protein Expr Purif. 2004;36:165-9. https://doi.org/10.1016/j. pep.2004.04.016.

39. Jones KL, O'Melia CR. Ultrafiltration of protein and humic substances: effect of solution chemistry on fouling and flux decline. J Memb Sci. 2001;193:163-73. https://doi.org/10.1016/S0376-7388(01)00492-6.

40. Kim KJ, Fane AG, Fell CJD, Joy DC. Fouling mechanisms of membranes during protein ultrafiltration. J Memb Sci. 1992;68:79-91. https://doi. org/10.1016/0376-7388(92)80151-9.

41. Chen K, Liu X, Long L, Ding S. Cellobiose dehydrogenase from Volvariella volvacea and its effect on the saccharification of cellulose. Process Biochem. 2017;60:52-8. https://doi.org/10.1016/j.procbio.2017.05.023.

\section{Publisher's Note}

Springer Nature remains neutral with regard to jurisdictional claims in published maps and institutional affiliations. 